\title{
Production and evaluation of particleboard made of sawdust and sugarcane bagasse with polyurethane resin based on castor oil
}

\section{Produção e avaliação de painéis de partículas de serragem e bagaço de cana com poliuretano a base de óleo de mamona}

\author{
Raissa Pravatta Pivettal \\ Ana Laura Soler Cunha Buzo" \\ Estéfani Suana Sugahara'"I \\ Sérgio Augusto de Mello da Silvalv
}

\begin{abstract}
Among the goals for sustainable development in Brazil, studies have been conducted to better use of industrial and agricultural waste to promote adequate final disposal of these and generate new materials that minimize the exploitation and use of natural resources. In this work, the proposal is to make and evaluate boards with nominal density of 0.80 g.cm-3 using sugar cane bagasse, sawdust and polyurethane resin derived from castor oil. Thus, three treatments with different percentages of particles and $10 \%$ of PU-castor were proposed for the preparation of boards that were pressed with a pressure of $50 \mathrm{kgf.cm}-2$, a temperature of $100^{\circ} \mathrm{C}$ and a pressing time of ten minutes. The boards were evaluated for their physical properties (density, moisture content and swelling) and mechanical (static flexure and perpendicular traction) according to NBR 14810: 2-2013 and presented average values density of 936 to $937 \mathrm{~kg} . \mathrm{m}-3$, swelling after 24 hours of 5.0 to $7.2 \%$, modulus of resistance to static bending of 22 to $23 \mathrm{MPa}$ and perpendicular traction of 0.71 to $0.87 \mathrm{MPa}$. The results obtained with the tests indicate the great potential of use of sugarcane bagasse and sawdust to produce boards of high density particles.
\end{abstract}

Keywords: Particleboards; Wood waste; Agroindustrial waste

\section{Resumo}

Dentre as metas para um desenvolvimento sustentável, no Brasil são realizados estudos para melhor aproveitamento de resíduos industriais e agrícolas de forma a promover adequada disposição final destes e gerar novos materiais que minimizem a exploração e o uso de recursos naturais. Neste

\footnotetext{
' Graduanda, Departamento de Engenharia Civil, Universidade Estadual Paulista - UNESP, Ilha Solteira, SP, Brasil. raissa_ppivetta@hotmail.com

" Mestrandas, Departamento de Engenharia Civil, Universidade Estadual Paulista - UNESP, Ilha Solteira, SP, Brasil. analaurasolercunha@gmail.com

III Mestrandas, Departamento de Engenharia Civil, Universidade Estadual Paulista - UNESP, Ilha Solteira, SP, Brasil. estefanisugahara@hotmail.com

IV Doutor, Departamento de Engenharia Civil, Universidade Estadual Paulista - UNESP, Ilha Solteira, SP, Brasil.
} 
trabalho, propõe-se confeccionar e avaliar painéis de partículas com densidade nominal de 0,80 g.cm-3 empregando-se bagaço de cana-de-açúcar, serragem e adesivo poliuretano bicomponente derivado de óleo de mamona. Assim, foram propostos três tratamentos com porcentagens diferentes de partículas e 10\% de PU-Mamona para confecção de painéis que foram prensados com pressão de $50 \mathrm{kgf.cm}-2$, temperatura de $100{ }^{\circ} \mathrm{C}$ e tempo de prensagem de dez minutos. Os painéis foram avaliados em suas propriedades físicas (densidade, umidade e inchamento) e mecânicas (flexão estática e tração perpendicular) de acordo com a NBR 14810:2-2013 e apresentaram valores médios de densidade de 936 a 937 kg.m-3, Inchamento após 24h de 5,0 a 7,2\%, módulo de resistência à flexão estática de 22 a $23 \mathrm{MPa}$ e resistência à tração perpendicular de 0,71 a 0,87 MPa. Os resultados obtidos com os ensaios indicam o grande potencial de utilização de bagaço de cana e serragem para produção de painéis de partículas de alta densidade.

Palavras-chave: Painéis de partículas; Resíduos de madeira; Resíduos agroindustriais 


\section{Introduction}

The exponential growth of the world population with the rise in industrial activities had the effect of increasing the demand for raw materials and also of the generation of waste. Waste is material discarded in production and consumption chains that, due to technological or market limitations, end up not having use or economic value, and may cause negative impacts to the environment when handled improperly (NOLASCO, 1998).

Forest-based industries in Brazil generate a significant amount of waste during the operational phases, from logging to the final product. In the study carried out by Cerqueira et al. (2012) it was verified that the main wastes generated by sawmills are sawdust (36.17\%), firewood (25.53\%), woodcuts (23.40\%) and wood chips (12.77\%) and that for every $1.720 \mathrm{~m}^{3}$ of wood processed annually, $396.6 \mathrm{~m}^{3}$ of waste is generated, thus creating a scenario of low technological level and bad use of wood due to the large amount of waste generated. This volume shows the great potential of using these materials to produce particleboard.

According to the Brundtland Report (1988), sustainable development must be understood as a transformation process in which resource exploitation, investment direction, technological development orientation and institutional change meet the needs of the present without compromising the future generations to meet their own needs.

In this way, the lumber sector focused on improving environmental performance using new inputs, such as in the process of producing boards with biodegradable adhesives and various vegetable residues such as tree pruning, bark, sugarcane, wood chips and other. The use of lignocellulosic residues in the production of agglomerates has been considered sustainable by reducing the use of natural wood and extending the life of landfills (SANTOS et al., 2014).

The agglomerated wood is a board formed of wood particles. The wood is chopped and processed into particles that are subjected to drying. The material, 
already dry, receives a resin; then, it is compressed to a certain temperature and pressure and, thus, forms the board (TOMASELLI, 2000).

Particleboards, compared to solid wood, have greater dimensional stability, lower weight and lower cost. In the manufacturing process, it is observed a lower energy expenditure with less production time and less effort, and it is possible to increase special properties such as thermal and acoustic (SILVA, 2016).

Thus, since industry depends on the environment directly and indirectly, reducing the maximum possible demand for raw material is crucial for the survival of the market in a resource-constrained world. The benefits are not only environmental but also economical, reducing costs and reliance on external suppliers (SARAVIACORTEZ et al., 2013).

According to data from National Food Supply Company - CONAB, in Brazil, the estimated sugarcane harvest for 2017/2018 will be 646.4 million tons, which represents, for the country, approximately 181 million tons of sugarcane bagasse, since, according to Silva et al. (2007), each processed ton of sugar cane generates a total of $280 \mathrm{~kg}$ of waste.

Generally, sugarcane bagasse is burned for energy production for industrial use, but given its physicochemical characteristics, and because it is a renewable source of raw material, it is being used in a wide field of research.

The production of particleboard with lignocellulosic residues is an alternative that provides added value to this by-product, making it possible to meet the growing demand of the wood boards industry, as well as contributing to a decrease in the use of wood and consequently the pressure on forests, reducing the cost of producing the boards, making them more competitive in the economic scenario (MENDES et al., 2010).

NBR 14810-1 (ABNT, 2013) defines adhesive or resin as a substance used with the purpose of adhering wood particles to a board, which may have an organic or inorganic origin. The main resins used in the wood board industry are synthetic ones which, according to some studies, have presented some unsatisfactory points due to the low resistance to the action of humidity and the release of formaldehyde gas 
when heated, which damages the environment. Therefore, it is necessary to find a substitute with the same quality and performance as the traditional resins (ZAU et al., 2014).

In addition, there is a worldwide trend towards the use of biodegradable, nonpolluting products from renewable sources. According to Araújo (1992), this trend has advanced research, leading to the discovery of a polyurethane derived from castor oil, presented as a resin in the bicomponent formulation.

Therefore, in order to develop sustainable products and the use of industrial and agricultural byproducts that can add value to these materials and promote an adequate final disposal that avoids the burning of material, this work has the objective to evaluate the applicability of residues in the manufacture of agglomerated boards using sawmill waste, sugarcane bagasse and alternative resin derived from castor oil.

\section{Materials and methods}

\subsection{Materials}

For the preparation of the boards, particles collected from sawmills and sugar and alcohol industries located at the region of Ilha Solteira (São Paulo) were used and three treatments were proposed (Table 1), using sugarcane bagasse residues in association with the sawing of several native woods.

Table 1 - Proposed treatments for confection of agglomerated boards

\begin{tabular}{cccc}
\hline Treatments & Bagasse (\%) & Sawdust (\%) & Resin (\%) \\
\hline T1 & 100 & 0 & 10 \\
\hline T2 & 80 & 20 & 10 \\
\hline T3 & 60 & 40 & 10 \\
\hline
\end{tabular}

For particle agglutination, a bicomponent polyurethane derived from castor oil (PU-Castor) was used in the ratio of $10 \%$ to the dry mass of the particles. 


\subsection{Methods}

Initially, the waste passed through a manual selection, where the strange materials were removed, and, after, the remaining materials were taken for processing in the knife mill to adjust the particle size.

Then, the sugarcane bagasse and sawdust particles were graded in an assay using NBR NM 248-2003 as a reference, in which a particulate stirrer with a vibratory system was used to determine the modulus of fineness of the particulate mixture according to the retained percentages of material in each sieve of the whole set.

After grading, the particles were selected using only the ones with dimensions between 2 and $6 \mathrm{~mm}$ in length, then the material was dried in the sun until a mean humidity of $10 \%$ was reached.

From the nominal density of $0.80 \mathrm{~g} \cdot \mathrm{cm}^{-3}$, the masses of the particles to be used in the production of the boards were calculated according by the percentages defined for the proposed treatments, and then nine boards were created with dimensions of $35 \times 35 \times 1 \mathrm{~cm}$.

After the preparation of the materials, the boards were created, as can be seen in the sequence shown in Figure 1. The particles were homogenized in two stages to provide greater uniformity of the PU-Castor resin in the mixture, initially the polyol and then the prepolymer, where the homogenization was done first manually and then using a rotational particle gluer.

The sequence of images presented in Figure 1 illustrates the preparation of the boards starting with the homogenization of the particles with PU-Castor, preparation of the "particle mattress" in the "mattress forming" with press pressure of 5 tons where the "mattress forming" was subjected to the hydraulic press with a measured pressure of $50 \mathrm{kgf}_{\mathrm{cm}} \mathrm{cm}^{-2}$ and a temperature of $100{ }^{\circ} \mathrm{C}$ for 10 minutes of pressing, with initial time of 3 minutes with intervals of 30 seconds for relief of pressure, in order to avoid the formation of gases and delamination of the boards. 
Figure 1 - Sequence of confection of agglomerated boards

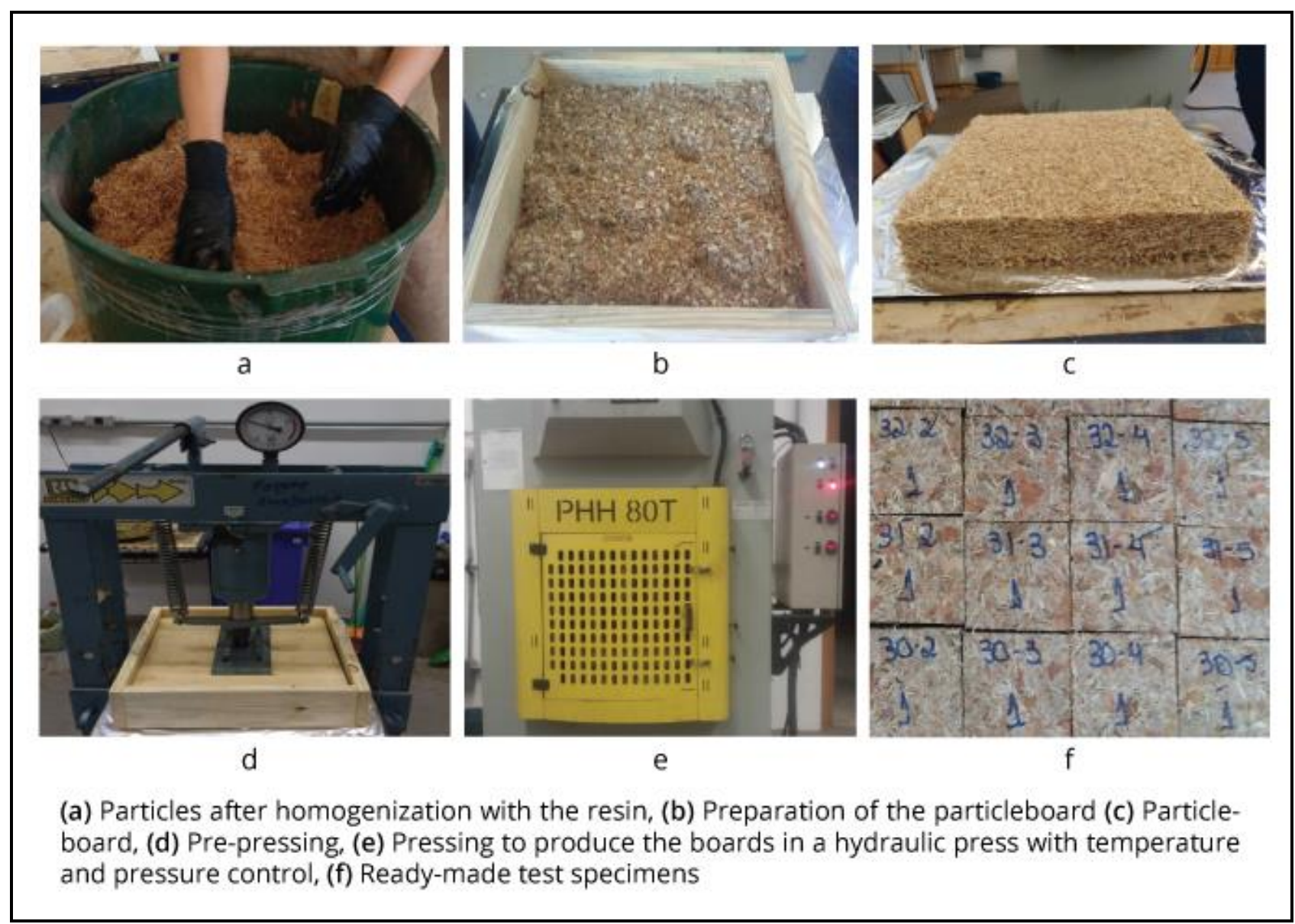

Source: Own author

Three boards were prepared for each treatment. After $72 \mathrm{~h}$ they were squared and from them, the test specimens were produced to evaluate the physical and mechanical properties according to the essays from NBR 14810: 2-2013.

Ten test specimens measuring $(50 \times 50) \mathrm{mm}$ were used for each test to determine the physical characteristics. To calculate the density of the boards, it was necessary to determine the dimensions of the test specimens with pachymeter and micrometer and their respective masses. In the moisture content test, the test specimens were weighed on analytical balance before and after drying for 24 hours in an oven at $100^{\circ} \mathrm{C} \pm$. And for the swelling test, the thickness at the point of intersection of the diagonals was measured before and after the test specimens were submerged in deionized water for 24 hours. 
In the mechanical characterization of the boards, the EMIC universal testing machine was used. Thus, for the static flexural test, ten specimens were used in the dimensions (20 times the thickness $+50 \mathrm{~mm}$ ) $\times 50 \mathrm{~mm}$ that were positioned on two supports of the universal machine, the length of the span being ten times the thickness of the body ( $200 \mathrm{~mm}$ minimum). To determine the tensile strength perpendicular, ten test specimens were prepared in the dimensions $(50 \times 50) \mathrm{mm}$, which were fixed with Super Bonder in metallic supports.

\section{Results and discussion}

In this item, it is presented the values obtained with the tests to characterize the physical properties: density, moisture content, swelling after 24 hours, and the mechanical properties: modulus of resistance to static bending (MOR) and perpendicular traction. The values obtained were compared with the requirements established by standard NBR 14810-2 (ABNT, 2013).

Based on the tests for the granulometric composition of the materials, the fineness modules of sugarcane bagasse (3.0) and sawdust (5.2) were determined, that is, the particles of treatments T1, T2 and T3 are contained in a length range of 2 to 6 $\mathrm{mm}$.

\subsection{Physical Properties}

Table 2 presents the mean values determined for density, moisture content, swelling after $24 \mathrm{~h}$.

Table 2 - Determined physical properties

\begin{tabular}{|c|c|c|c|}
\hline NBR 14810-2:2013 & 550 a $750\left(\mathrm{~kg} \cdot \mathrm{m}^{-3}\right)$ & 5 a $13(\%)$ & $18(\%)$ \\
\hline Treatment & Density & Moisture content & Swelling $24 \mathrm{~h}$ \\
\hline $\mathrm{T1}(100 \times 0)$ & 937 & 9,7 & 7,1 \\
\hline$\overline{T 2(80 \times 20)}$ & 937 & 10,3 & 7,2 \\
\hline T3(60x40) & 936 & 10,0 & 5,0 \\
\hline
\end{tabular}


The analysis of the results obtained with the tests to characterize the apparent density of the treatments T1, T2 and T3, indicate, in accordance with NBR 14810-2: 2013, that the boards can be classified as high density. According to Torquato (2008), high density boards have better machining and consequently satisfactory finishing. According to Kelly (1977) cited by Iwakiri (2005), boards of higher density have greater mechanical resistance.

According to the moisture content, Table 2 shows that the determined values are in accordance with the requirements of NBR 14810-2: 2013. According to Bertolini (2011), the ideal moisture content of the boards made with PU-Castor must be in the range of 8 to 10\%, in the treatments T1, T2 and T3 the particles were with a humidity of $10 \%$.

As for the test for swelling evaluation after $24 \mathrm{~h}$, it is observed that the values obtained for all boards meet the minimum standards that define boards for use in humid conditions, whose limit is $13 \%$. This assay makes it possible to infer the efficiency of the PU-Castor within the board when subjected to immersion in water. According to Fiorelli et al. (2011), industrially marketed boards are meticulously subjected to this type of test for satisfactory quality control.

The swelling values obtained for the boards of the T2 and T3 treatments may be related to the proposed particle size composition, the adhesion between the particles, the reduction of voids within the boards and, consequently, better resistance to swelling.

In the research conducted by Iwakiri et al. (2012), for wood boards agglomerated with sawdust residues and $8 \%$ urea formaldehyde resin the results of swells obtained varied between $10.97 \%$ and $22.37 \%$, being therefore larger than those obtained in this work with boards s made with PU-Castor, which shows the efficiency of the enveloping and adhesion between the particles and, consequently, greater resistance to swelling. 


\subsection{Mechanical Properties}

Table 3 shows the MOR and perpendicular traction values. These values were compared with the minimum values required by the NBR, whose use is justified by the similarity of the product developed in the present study with a board of wood particles.

Table 3 - Determined values for resistance properties of the boards

\begin{tabular}{ccc}
\hline $\begin{array}{c}\text { NBR 14810- } \\
\text { 2:2013 }\end{array}$ & 18 (MPa) & $0,45(\mathrm{MPa})$ \\
\hline Tratamento & MOR & $\begin{array}{c}\text { Perpendicular } \\
\text { traction }\end{array}$ \\
\hline T1 & 22 & 0,77 \\
\hline T2 & 22 & 0,71 \\
\hline T3 & 23 & 0,87 \\
\hline
\end{tabular}

When analyzing the values obtained in the modulus of resistance to static bending (MOR) and resistance to perpendicular traction of the boards (Table 3), it is observed that all treatments reached values higher than the minimum required by NBR 14810-2: 2013.

In relation to MOR, it is verified that the average values reached are close to those obtained by Fiorelli et al. (2011), Battistelle et al. (2009), Contreras et al. (2006), Silva et al. (2008), Widyorini et al. (2005), Okino et al. (1997), in researches with cane bagasse particles and synthetic resins. Regarding perpendicular traction, it can be observed that the mean values reached are higher than those obtained by Battistelle et al. (2009) and Okino et al. (1997). These results confirm that the PU-Castor resin has adhesive potential for the manufacture of boards, that the manufacturing process used was adequate and that the amount of resin used provided effective results to produce boards of high density particles. 


\section{Final Thoughts}

Sugarcane bagasse is a large-scale agroindustrial by-product that has great potential for use in particle board production, given the positive results obtained with the physical and mechanical tests that, for the boards of the three treatments, maintained within the specifications of the standard. The production of boards adds value to this waste that is a renewable source of raw material.

It was verified that the proposed composition of the mixture to produce the boards was efficient, independent of the wood species contained in the sawdust, because, when analyzing the values obtained with the physical and mechanical tests of the boards, it was verified that the use of these wastes enables the production wood boards according to the normative requirements.

The PU-Castor for the swelling property was presented efficient, with better results in relation to the urea formaldehyde resin. Thus, PU-castor oil is an effective alternative to the property of waterproofing, in addition to being biodegradable and renewable source of raw material.

Regarding the mechanical properties of the boards and according to ABNT NBR 14810-1 and 2: 2013, the results obtained make it possible to classify the boards as "Type P4", ie "Structural boards for use in dry conditions".

In this context, it is evident that the use of residues, in the case of sugarcane bagasse, sawdust and the use of PU resin, besides the environmental contribution, it is a viable alternative for the manufacture of agglomerated boards that can be used in the production of furniture and in various applications in civil construction.

\section{Acknowledgments}

The authors are grateful to the Postgraduate Program of the Faculty of Engineering of Ilha Solteira, Universidade Estadual Paulista, CNPq and Capes for the support provided to the development of this work. 


\section{References}

ABNT - Associação Brasileira de Normas Técnicas. NBR NM 248: Agregados Determinação da composição granulométrica. Rio de Janeiro, 2003.

ABNT - Associação Brasileira de Normas Técnicas. NBR 14810-1: Painéis de partículas de média densidade - Parte 1: Terminologia. Rio de Janeiro, 2013.

ABNT - Associação Brasileira de Normas Técnicas. NBR 14810-2: Painéis de partículas de média densidade - Parte 2: Requisitos e Métodos de Ensaio. Rio de Janeiro, 2013.

ARAÚJO, L. C. R. Caracterização química e mecânica de poliuretanas elastométricas baseadas em materiais oleoquímicos. São Carlos, 1992. Dissertação (Mestrado) Instituto de Física e Química de São Carlos - USP.

BATTISTELLE, R. A. G.; MARCILIO, C.; LAHR, F. A. R. Emprego do bagaço da cana-deaçúcar (saccharum officinarum) e das folhas caulinares do bambu da espécie dendrocalamus giganteusna produção de chapas de partículas. Revista Minerva, v. 5, n. 3, p. 297-305, 2009.

BERTOLINI, M. S. Emprego de resíduos de Pinus sp tratado com preservantes CCB na produção de chapas de partículas homogêneas utilizando resina poliuretana à base de mamona. 2011. 128 f. Dissertação (Mestrado) - Escola de Engenharia de São Carlos, Instituto de Física de São Carlos, Instituto de Química de São Carlos da Universidade de São Paulo, São Carlos, 2011.

CERQUEIRA, P. H. A. ET AL. Análise dos resíduos madeireiros gerados pelas serrarias do município de Eunápolis-BA. Floresta e Ambiente, [s.I.], v. 19, n. 4, p.506-510, 2012. FapUNIFESP (SciELO). Available from: http://dx.doi.org/10.4322/floram.2012.051

CMMAD - Comissão Mundial Sobre Meio Ambiente e Desenvolvimento. Relatório Brundtland, 1988, p. 49.

CONAB - Companhia Nacional de Abastecimento. Acompanhamento da safra brasileira: cana-de-açúcar. Safra 2017/18, Segundo levantamento, v. 4, n. 2, ago. 2017.

CONTRERAS, W. M.; OWEN, M. E. C.; CLOQUELL, V. B.; CONTRERAS, Y. M.; GARAY, D. A. J. Diseño de tableros de partículas de caña brava y adhesivo fenol - formaldehído. Revista Forestal Latinoamericana, v. 21, n. 39, p. 39- 55, 2006.

SANTOS, M.F.N., BATTISTELLE, R.A.G., BEZERRA, B.S., VARUM, H.S.A. Comparative study of the life cycle assessment of particleboards made of residues from sugarcane bagasse (Saccharum spp.) and pine wood shavings (Pinus elliottii). Journal of Cleaner Production, Volume 64, Issue undefined, 1 February 2014.

FIORELLI, J. ET AL. Painéis de partículas à base de bagaço de cana e resina de mamona - produção e propriedades. Acta Scientiarum Technology, v.33, n.4, p.401-406, 2011. 
IWAKIRI, S. Painéis de madeira reconstituída. Ed. FUPEF - Fundação de Pesquisas Florestais do Paraná. Curitiba, PR, p.123-166, 2005.

MANDES, R. F. Painéis aglomerados produzidos com bagaço de cana em associação com madeira de eucalipto. Scientia Forestalis, Piracicaba, v. 38, n. 86, p. 285-295, jun. 2010.

NOLASCO, A. M. Resíduos florestais. Piracicaba: ESALQ/ USP, Departamento de Ciências Florestais, 1998.

OKINO, E. Y. A.; ANDAHUR, J. P. V.; SANTANA, M. A. E.; SOUZA, M. R. Physicomechanical properties of chemically modified sugar cane bragasse partideboards. Scientia Forestalis, v. 1, n. 52, p. 35-42, 1997.

SARAVIA-CORTEZ, A.M.; HERVA, M., GARCÍA-DIÉGUEZ, C.: ROCA, E.. Assessing environmental sustainability of particleboard production process by ecological footprint. Journal of Cleaner Production v52, p. 301 e 308, 2013.

SILVA, V. L. M. M.; GOMES, W. C. O.; ALSINA, L. S. Utilização do bagaço de cana de açúcar como biomassa adsorvente na adsorção de poluentes orgânicos. Revista Eletrônica de Materiais e Processos v 2, p.27-32, 2007.

SILVA, A. J. P.; FRANÇA SANTOS, W. L.; ROCCO LAHR, F. A. Partículas longas e orientadas de bagaço de cana-de-açúcar na produção de painel similar ao OSB. In. ENCONTRO BRASILEIRO EM MADEIRA E ESTRUTURAS DE MADEIRA, 11., 2008, Londrina. Anais[...] Londrina: UEL, IBRAMEM, 2008.

SILVA, S. A. M. Confecção e avaliação de painéis de partículas de madeira de média densidade com aproveitamento de resíduos industriais. 2016. $92 \mathrm{f}$. Tese (Doutorado) Curso de Engenharia Civil, Unesp, Ilha Solteira, 2016. Cap. 1.

TOMASELLI, I. Tendências de mudanças na indústria de painéis. Revista da Madeira, Sao Paulo, v.8, n.43, p.36-42, 1999.

TORQUATO, L. P. Caracterização dos painéis MDF comerciais produzidos no Brasil. 2008. 94 f. Dissertação (Mestrado) - Curso de Engenharia Florestal, Universidade Federal do Paraná - UFPR, Curitiba, 2008.

WIDYORINI, R.; XU, J.; UMEMURA, K.; KAWAI, S. Manufacture and properties of binderless particleboard from bagasse: effects of raw material type, storange methods and manufacturing process. Journal of Wood Science, v. 51, n. 6, p. 648-654, 2005.

ZAU, M. D. L. et al. Avaliação das propriedades química, física e mecânica de painéis aglomerados produzidos com resíduo de madeira da Amazônia - Cumaru (Dipteryx Odorata) e resina poliuretana à base de óleo de mamona. Polímeros, São Carlos, v. 24, n. 6, p.101-108, dez. 2014. 